\title{
Prosecuting Dirty Dumping in Africa
}

\author{
MATIANGAI V.S. SIRLEAF
}

\section{INTRODUCTION}

We talk of globalization, of the global village, but here in Africa we are under the impression of being that village's septic tank.

- Haïdar el Ali, Senegalese former Minister of Ecology

The African Union (AU) ${ }^{1}$ adopted the Protocol on Amendments on the Protocol on the Statute of African Court of Justice and Human Rights ${ }^{2}$ (hereinafter Malabo Protocol) to create the first ever regional criminal tribunal in June of 2014. ${ }^{3}$ The regional criminal tribunal criminalizes trafficking in

I would like to thank Ifeoma Ajunwa, Rabia Belt, Kamari Clarke and the Pitt Law Junior Faculty Forum for helpful comments on earlier drafts. I would also like to thank Jacqueline Jones for her research assistance. I take full responsibility for any errors. This book chapter was adapted with permission. See Matiangai Sirleaf, Not Your Dumping Ground: Criminalization of Trafficking in Hazardous Waste in Africa, 35 Wisc. J. Int'l L. 326-66 (2018)

(symposium issue).

1 Constitutive Act of the African Union, Lomé, 11 July 2000, in force 26 May 2001, 2158 U.N.T.S. I-37733 [hereinafter AU Constitutive Act]. For more on the transition from the Organization of African Unity (OAU) to the AU see generally, Abou Jeng Peacebuilding in the African Union: Law, Philosophy and Practice (Cambridge: Cambridge University Press, 2012) p. 111.

2 Protocol on Amendments to the Protocol on the Statute of the African Court of Justice and Human Rights, Malabo, 27 June 2014, available at http://au.int/en/treaties/protocolamendments-protocol-statute-african-court-justice-and-human-rights.

3 See id., art. 16. The Assembly of the AU adopted the Malabo Protocol on 27 June 2014 at its Twenty-Third Ordinary Session. See A.U. Doc. No. Assembly/AU/Dec.529 (XXIII). The regional Court's criminal law section will be composed of a Pre-Trial Chamber, a Trial Chamber, and an Appellate Chamber. Malabo Protocol, supra note 3, art. 16(2). See also Dinah L. Shelton \& Paolo G. Carroza, Regional Protection of Human Rights, Second Edition (New York: Oxford University Press, 2013) 1019. In the book, this is characterized as 'revolutionary'. 
hazardous waste, ${ }^{4}$ and presents an opportunity for African states to alter the status quo in environmental protection. Trafficking in hazardous waste is something that none of the existing international criminal tribunals have jurisdiction over. ${ }^{5}$ African states may be particularly sensitive to concerns about toxic waste, given a history of negative external interventions. ${ }^{6}$ This chapter argues that regional cooperation through the criminal tribunal might assist with more effective prosecution of toxic dumping incidents. This is especially so because the Malabo Protocol provides for corporate criminal liability, ${ }^{7}$ which presents a significant innovation for the field of international criminal justice. ${ }^{8}$

This chapter examines how the AU's adoption of the Malabo Protocol seeks to improve upon the limitations of the international legal framework for regulating hazardous waste. Little to no scholarship exists on the Malabo Protocol's provision criminalizing trafficking in hazardous waste. This chapter illuminates an under-researched area and provides a robust analysis of the criminalization of trafficking in hazardous waste in Africa. This chapter situates the Malabo Protocol's provision criminalizing the trafficking in

4 Malabo Protocol, supra note 3, art. 28L.

5 See generally Rome Statute of the International Criminal Court, July 1998, in force on a July 2002, 2187 U.N.T.S. 90 [hereinafter Rome Statute]; Statute International Criminal Tribunal for the former Yugoslavia, 25 May 1993, UN Doc. S/Res/827, available at www.icty.org/x/file/ Legal\%2oLibrary/Statute/statute_septo9_en.pdf [hereinafter ICTY Statute]; Statute International Criminal Tribunal for Rwanda, 8 November 1994, UN Doc. S/Res/955, available at www.unictr.org/Portals/o/English/Legal/Statute/2010.pdf [hereinafter ICTR Statute]; Statute of the Special Court for Sierra Leone, 16 January 2002), available at www.sc-sl .org/LinkClick.aspx?fileticket=uClndıMJeEw\%3d\&tabid=176 [hereinafter SCSL Statute]; see also generally S.C. Res. 1315, U.N. SCOR, 55th Sess., U.N. Doc S/RES/1315 (14 August 2000) on the establishment of the SCSL.

6 For further discussion, see Henry J. Richardson, 'African Grievances and the International Criminal Court: Issues of African Equity under International Criminal Law’ (2013), Africa and the Future of International Criminal Justice 81 (V.O. Nmehielle ed., Eleven 2012); Temple University Legal Study Research Paper No. 2013-24 available at SSRN: https://ssrn.com/ abstract=2285474. Justice, 91 (Vincent Nmehielle ed., 2012) (discussing the continent's history with slavery, colonialism, and neo-colonialism).

7 Malabo Protocol, supra note 3, art. 46C. This chapter relies on the broad definition of 'hazardous waste' in the Bamako Convention on the ban on the Import into Africa and the Control of Transboundary Movement and Management of Hazardous Wastes within Africa, Bamako, 30 January 1991, in force 22 April 1998 available at 30 I.L.M. 773, including wastes from particular streams in manufacturing processes, or hazardous constituent materials, wastes considered hazardous under the domestic laws of the country of export, import, or transit, as well as wastes outlawed in the exporting country due to human health or environmental reasons, and radioactive wastes. See id. art. 2, Annex I and Annex II of the Bamako Convention.

8 None of the existing international criminal tribunals provide for corporate criminal liability. Compare, Rome Statute, ICTY Statute, ICTR Statute and SCSL Statute supra note 6. 
hazardous waste as part of the larger environmental justice movement and the struggle against corporate, government, and individual polluters. Environmental justice is a contested term that has variously been defined by scholars as - signifying inequitable distribution, a lack of recognition, limited participation, a critical lack of capabilities, inequitable application of environmental regulations, and systematic exclusion from environmental policies and decisions amongst others. ${ }^{9}$ In the environmental justice literature, Robert Nixon has coined the term "slow violence" to describe a violence of delayed destruction that is "dispersed throughout time and space" to disposable bodies. ${ }^{10}$ His work draws attention to categories of violence that unfold over years and decades that is often exponential and operates as a major threat multiplier, in the same way that toxic dumping can. ${ }^{11}$ Such work complicates our understanding of violence because it does not conceive of violence as spectacular, or immediately sensational, or hyper-visible. ${ }^{12}$ The concept of slow violence allows us to consider more forcefully the violence caused by environmental harms like toxic dumping.

The dumping of toxic waste in the Global South, and particularly in African countries is by no means an exceptional, or recent phenomenon. ${ }^{13}$ This chapter will demonstrate the problematic trend of 'toxic colonialism,' in which African states are used as 'disposal sites for waste rejected' by more developed states. ${ }^{14}$ The term 'colonialism' is used to signify the relationship between countries in the Global North that export the risks of toxic waste to countries in the Global South, who do not 'share in the benefits of the production process that generate those wastes'. ${ }^{15}$ This pattern resembles some of the characteristics of historical colonialism in that toxic colonialism is similarly driven by economic dependence, exploitation, and inequality. ${ }^{16}$

9 See Workineh Kelbessa, 'Environmental Injustice in Africa,' (2012) 9 Contemporary Pragmatism, 99-132.

10 Rob Nixon, Slow Violence and the Environmentalism of the Poor 2 (Boston: Harvard University Press, 2011) (discussing the analogous concept of slow violence).

${ }^{11}$ Id. at 3 .

12 Id. At 3 .

13 See Rob White, 'Toxic Cities: Globalizing the Problem of Waste' (2008), 35 Social Justice 107.

14 Laura A. Pratt, 'Decreasing Dirty Dumping? A Reevaluation of Toxic Waste Colonialism and the Global Management of Transboundary Hazardous Waste' (2011), 41 Texas Environmental Law Journal, 147, 151. The chapter discusses how the term 'toxic colonialism' was coined by Greenpeace to describe the dumping of 'industrial wastes of the West on territories of the Third World.'

15 See e.g. Samuel Atteh, 'Political Economy of Environmental Degradation: The Dumping of Toxic Waste in Africa' (1993), 30 International Studies, 277, 278 discussing the unfairness of this relationship.

16 See Pratt, ‘Decreasing Dirty Dumping?’ p. 152. 
As I noted elsewhere, regime complexes consist of 'several legal agreements that are created and maintained in distinct fora with participation of different sets of actors. ${ }^{17}$ They allow for greater creativity and flexibility. This adaptability is evident in the types of crimes covered by the regional criminal court, especially the attempt to regulate the trafficking in hazardous waste.

This chapter is organized as follows: Section 2 provides a brief background on how the history of toxic colonialism in Africa helped to inform the attempt to criminalize the trafficking of hazardous waste in the Malabo Protocol. Section 3 explores instead how the inadequate international legal framework for regulating hazardous waste, led to the criminalization of trafficking in hazardous waste in the Malabo Protocol. Section 4 analyzes how the regional prosecution of trafficking in hazardous waste contributes towards some of the newer theories of punishment, as well as some of the more traditional goals of punishment. This section also discusses how any potential challenges might be resolved through creative interpretation of the Protocol. Lastly, this chapter concludes that the regional criminal court's prosecution of trafficking in hazardous waste presents another option for African states whose domestic judiciaries and related institutions may not be able to prosecute trafficking in hazardous waste, and the international system, which has failed to prosecute trafficking in hazardous waste or corporations involved in toxic dumping.

\section{OVERVIEW OF TOXIC COLONIALISM IN AFRICA}

All of the toxic dumping incidents discussed in this section share the disturbing pattern of toxic colonialism, marked by economic dependence, exploitation, and inequality.

\section{A. The Global Increase and Causes of Trafficking in Hazardous Waste}

In 2000 , the worldwide generation of hazardous waste was four hundred million metric tonnes, with almost all of this amount originating from developed nations. ${ }^{18}$ It is estimated that by 2020 , the total production of hazardous waste in the Global North will have increased by $60 \%$ annually. ${ }^{19}$ Most of the estimates of the transboundary movement of hazardous waste from the Global

${ }^{17}$ Kal Raustiala \& David Victor, 'The Regime Complex for Plant Genetic Resources' (2004). 58 International Organizations 277, 279.

18 See David Hunter, James Salzmann and Durwood Zaelke, 'International Environmental Law and Policy' Third Edition (New York: Foundation Press 2007).

19 See David Naguib Pellow, 'Resisting Global Toxics: Transnational Movements for Environmental Justice' (Massachusetts: The MIT Press 2007). 
North to the Global South are quite small. ${ }^{20}$ However, all of the estimates are based on the legal transfer of hazardous waste, as the quantification of 'illegal transboundary exchanges of hazardous waste is much more difficult. ${ }^{21}$

Irrespective of the exact amount of hazardous waste; toxic dumping in Africa is a significant problem for a number of reasons. People that are exposed to toxic waste can experience dire health consequences ranging from respiratory problems, birth defects, burns, miscarriages, nausea, severe headaches, paralysis, frequent illness, irritation of the eyes and skin, various types of cancer, brain damage, intestinal disease, stunted growth, harm to the immune system, pathological conditions, and death. ${ }^{22}$ If not properly treated, toxic waste can not only threaten human life, but also lead 'to ecological, geological, and environmental disasters' as contaminated 'soil, groundwater, and streams can endanger public health and the environment. ${ }^{23}$ A significant percentage of Africans live in rural areas that are dependent on groundwater and streams for domestic and agricultural uses. ${ }^{24}$ In addition, the disposal of hazardous waste in landfills can easily result in water and food contamination. ${ }^{25}$ The lack of the necessary infrastructure including facilities, environmental technology, and economic resources means that toxic dumping on the Continent has much more devastating consequences, than it does elsewhere. ${ }^{26}$

Given all of these negative consequences, why does toxic colonialism persist? The key driver is profit. ${ }^{27}$ Toxic colonialism is also furthered by certain structural changes of and in the global system, including the restructuring of the nation-state and the growth of interdependence,. ${ }^{28}$ The age of globalization ${ }^{29}$ is marked by the increased mobility of capital and competition amongst states to attract foreign direct investment. For example, the amount of money offered for permission to import hazardous waste into

20 See e.g. Hunter et al. 'International Environmental Law and Policy', p. 947 estimating that only $4 \%$ of the generated hazardous waste actually travels across borders.

${ }^{21}$ Pratt 'Decreasing Dirty Dumping?' p. 153.

22 Id. see also Kelbessa, 'Environmental Injustice in Africa,' p. 109.

23 Atteh, 'Political Economy of Environmental Degradation' p. 279.

24 Id.

25 Id.

${ }^{26}$ Id.

27 See Pratt 'Decreasing Dirty Dumping?' p. 154.

28 Anél Ferreira -Snyman, 'Regionalism and the Restructuring of the United Nations with Specific Reference to the African Union' (2011), 44 Comparative and International Law Journal of Southern Africa, 360, 362.

29 See Adam Lupel, 'Regionalism and Globalization: Post-Nation or Extended Nation?' (2004), 36 Polity 153,159 . Globalization is a term that 'summarizes a variety of processes that together increase the scale, speed, and effectiveness of social interactions across political, economic, cultural, and geographical borders.' 
African countries is reportedly sometimes more than the individual country's gross national product, or its total foreign debt. ${ }^{30}$ Accordingly, individual developing countries are dissuaded from taking measures that would place additional regulations on multinational corporations (MNCs) ${ }^{31}$ such as compliance with environmental and human rights obligations. ${ }^{32}$ For instance, in some African countries, there are "no real treatment process [es] and no proper storage'33 options for hazardous waste. Indeed, the United Nations Environment Program (UNEP) noted that it costs as little as \$2.50 per ton to dump hazardous waste [legally] in Africa as opposed to $\$ 250$ per ton in Europe. ${ }^{34}$ Consequently, since the late 1970 and early 1980s, toxic waste has been exported increasingly to Africa. ${ }^{35}$

\section{B. Historical Development of Toxic Colonialism in Africa}

Toxic colonialism is manifested in many different ways: from Western MNCs rarely having track records of safe waste disposal, to the receiving countries not being accurately informed about the dangers of the hazardous waste, ${ }^{36}$ to the lack of capacity of countries in the Global South to deal with the aftermath. In the mid-1980s a number African countries had private local companies, individuals, and governments 'openly or secretly' sign waste

30 See D.M. Dzidzornu, 'Marine Pollution Control in the West and Central African Region' (1995), 20 Queens Law Journal 439.

${ }^{31}$ Multinational corporations (MNCs) or transnational corporations (TNCs) are economic entities operating in more than one country or a cluster of economic entities operating in two or more countries. See Norms on the Responsibilities of Transnational Corporations and Other Business Enterprises with Regard to Human Rights, UN Doc. E/CN.4/Sub.2/2003/12/Rev.2 (2003).

32 See A. Lupel, 'Regionalism and Globalization: Post Nation or Extended Nation?’ p. 157, discussing how globalization challenges states in their: administrative effectiveness, territorial sovereignty, collective identity, and democratic legitimacy, available online at www.ipinst.org/ images/pdfs/lupel_polity_janzoo4.pdf.

33 F. Bridgland, 'Europe's New Dumping Ground: How the West's Toxic Waste is Poisoning Africa', The Herald, 1 October 2006 available online at http://archive.ban.org/ban_news/20o6/ o610o1_dumping_ground.html quoting the French environmental group 'Robin Hood of the Forest'.

34 United Nations Environmental Program, National Rapid Environmental Desk AssessmentSomalia, 2005, p. 135 [hereinafter UNEP Report] available online at www.unep.org/tsunami/ reports/TSUNAMI_SOMALIA_LAYOUT.pdf.

35 See Atteh, 'Political Economy of Environmental Degradation' p. 281 discussing French and the U.S. exporting 'enormous amounts of hazardous waste to Africa'.

${ }^{36}$ See James Brooke, 'Waste Dumpers Turning to West Africa', New York Times, 17 July 1988, available at www.nytimes.com/1988/o $/ 1 / 17$ world/waste-dumpers-turning-to-west-africa.html? pagewanted=all. 
disposal contracts with waste brokers. ${ }^{37}$ These contracts authorized waste brokers 'to use certain designated areas' for dumping hazardous waste. ${ }^{3}$ For example, the governments of Benin and Guinea-Bissau signed lucrative contracts with companies in the Global North to dump hazardous waste in their territories for a specified period of time. ${ }^{39}$ In Benin, the company falsely described the hazardous waste material in the ten-year contract as 'complex organic matter' and 'ordinary industrial wastes'.$^{40}$ In Guinea, a Norwegian shipping company brokered a deal in 1988, to dump on Kassa, a resort island not too far from the capital. ${ }^{41}$ The company unloaded 15,000 tonnes of a substance listed as 'raw material for bricks' in an abandoned quarry. ${ }^{42}$ Subsequently, visitors from the mainland noticed that the island's vegetation began to shrivel. ${ }^{43}$ A government investigation later discovered that in fact the material was incinerator ash from Philadelphia. ${ }^{44}$ The contract originally provided for the disposal of 85,000 tonnes of hazardous waste in Guinea. ${ }^{45}$ Following the incident, the government of Guinea arrested at least thirteen people, ${ }^{46}$ including the Norwegian Consul-General who was accused of forging an import licence to enable the company to import the hazardous waste. ${ }^{47}$ International furor ensued, and a Norwegian freighter completed removal of the hazardous waste in July of $1988.4^{8}$

This pattern of toxic colonialism is replicated in Somalia's experience with hazardous waste dumping. In 1992, Italian and Swiss MNCs purportedly negotiated an $\$ 80$ million, twenty-year contract with the 'Minister of Health' to dump toxic waste. ${ }^{49}$ This is despite the reality that Somalia was embroiled in a devastating civil war with none of the warring factions able to claim any

37 See Kelbessa, 'Environmental Injustice in Africa,' p. 109.

$3^{8}$ Atteh, 'Political Economy of Environmental Degradation' p. 281.

39 For further discussion see id. pp. 285-6.

40 Brooke, 'Waste Dumpers Turning to West Africa', p A 1.

$4^{11}$ See id.

$4^{2}$ See id.

43 See id.

44 See id. See also Mark Jaffe, 'Tracking the Khian Sea: Port to Port, Deal to Deal', The Philadelphia Inquirer, 15 July 1988 p. B1 available at http://articles.philly.com/1988-07-15/ news/26236354_1_khian-sea-coastal-carriers-incinerator-ash discussing how efforts to dispose of the Philadelphian ash failed in Chile, Honduras, Haiti, the Bahamas, the Dominican Republic, Costa Rica, before it reached the West Coast of Africa.

45 See Brooke, 'Waste Dumpers Turning to West Africa'.

$4^{6}$ See Barbara Hunton, 'Emerging Controls on Transfers of Hazardous Waste to Developing Countries' (1989), 21 Law and Policy International Business p. 247.

47 See Atteh, 'Political Economy of Environmental Degradation' p. 283.

$4^{8}$ See Brooke, 'Waste Dumpers Turning to West Africa'.

49 Hao-Nhien Q. Vu, 'The Law of Treaties and the Export of Hazardous Waste' (1994), 12 University of California, Los Angeles Journal of Environmental Law and Policy 389, 390. 
sense of legitimacy or hold on power. The dumping began in the early 1980 s and continued during the civil war. ${ }^{50}$ The financial arrangements undoubtedly helped to fuel the conflict and provided powerful incentives to the various warlords to ignore environmental and public health repercussions. ${ }^{51}$ The dumping of toxic waste in Somalia gained renewed international attention following the 2004 tsunami. ${ }^{2}$ The waves from the tsunami exposed containers, which held 'radioactive waste, lead, cadmium, mercury, flame retardants, hospital waste, and cocktails of other deadly residues' on Somalia's shores. 'Subsequent cancer clusters have also been linked to Europe's special gift to the country, delivered by that tsunami. ${ }^{53}$ A report by UNEP said the release of the deadly substances, has caused:

health and environmental problems to the surrounding local fishing communities including contamination of groundwater. Many people in these towns have complained of unusual health problems as a result of the tsunami winds blowing towards inland villages. The health problems include acute respiratory infections, dry heavy coughing and mouth bleeding, abdominal hemorrhages, unusual skin chemical reactions, and sudden death after inhaling toxic materials. ${ }^{54}$

Italian authorities initiated an investigation into the company's hazardous waste trade in 1997. ${ }^{55}$ Due to the continued violence and political instability in Somalia the prospects for a successful clean-up are limited.

The problematic pattern of countries in the Global North exporting the risks of toxic waste to countries in the Global South, who do not share in the benefits of the production process of the waste is also exhibited in Nigeria's experience. ${ }^{56}$ In Nigeria, a businessman permitted two Italian MNCs to use his residential property to store 18,000 drums of hazardous waste in $1987 .{ }^{57}$ It was located in Koko, Nigeria a small rural community located on the river Niger..$^{8}$ The Line ship (registered in Germany) was refused entry in Europe

$5 \circ$ See UNEP Report p. 134.

${ }^{51}$ See Bridgland 'Europe's New Dumping Ground'.

$5^{2}$ See Kelbessa, 'Environmental Injustice in Africa,' p. 109.

53 Bridgland, 'Europe's New Dumping Ground'.

54 UNEP Report p. 134.

55 See Kelbessa, 'Environmental Injustice in Africa,' p. 110.

${ }^{6}$ For further discussion see e.g. Sylvia F. Liu, 'The Koko Incident: Developing International Norms for the Transboundary Movement of Hazardous Waste', (1992-1994) 8 Journal of Natural Resources and Environmental Law. 121; Obinna Anyadike, 'Toxic Terrorism' (1988), 3696 West Africa p. 1108; 'Nigeria: Koko’s Radioactive Waste' (1988), West Africa, p. 1388.

57 See Kelbessa, 'Environmental Injustice in Africa,' p. 109.

$5^{8}$ See Atteh, 'Political Economy of Environmental Degradation' p. 283. 
because the ship had been found to be carrying 'highly poisonous chemical waste' before it made its way to Nigeria.59 The businessman charged $\$ 100$ a month for the storage of the toxic waste. ${ }^{60}$ The ship delivered four shipments of the waste before media exposure of the crime alerted the Nigerian authorities. ${ }^{61}$ A Nigerian construction company falsified documents to the government, which allowed the company to import the toxic waste under the pretence that it was importing 'building materials. ${ }^{92}$ In the aftermath, nineteen individuals in the area died, including the businessman who stored the waste in his backyard. ${ }^{6}$ Other adverse effects included chemical burns, paralysis of a member of the crew who reloaded the waste, and the dockworkers that repackaged the waste on board the ship reportedly vomited blood. ${ }^{64}$ Nigeria's government responded forcefully - it recalled its ambassador to Italy, demanded that Italy remove the waste at once, and seized an Italian ship docked in its harbour to send the waste back to Italy. ${ }^{65}$ The government also enacted a decree making the trafficking in hazardous waste a capital crime, but later reduced the punishment to life imprisonment. ${ }^{66}$ It also passed a decree in 1988, which barred citizens from negotiating toxic waste contracts with foreign companies. ${ }^{67}$

The patterns of economic dependence, exploitation, and inequality also characterize the toxic dumping incident in Côte d'Ivoire, which occurred more than twenty years after the Nigerian and Somalian incidents. Outrage about toxic dumping in Nigeria in 1988 , led Côte d'Ivoire to adopt a law that provides for prison terms of up to 20 years and fines of up to $\$ 1.6$ million for individuals who import hazardous waste. ${ }^{68}$ In August of 2006, a ship named the Probo Koala charted by the Dutch-based oil and service shipping company Trafigura Beheer BV, offloaded toxic waste. The Probo Koala left the waste at the port of Abidjan, the capital city of Côte d'Ivoire. ${ }^{69}$ A local

59 Id.

60 See Kelbessa, 'Environmental Injustice in Africa,' p. 109.

${ }^{61}$ See Atteh, 'Political Economy of Environmental Degradation'.

62 Id. p. 284.

63 See id. p. 284.

64 Id. See also Kelbessa, 'Environmental Injustice in Africa,' p. 109.

65 See Atteh, 'Political Economy of Environmental Degradation'.

66 See Joel Millman, 'Exporting Hazardous Waste: From Developed to Third World Nations' (1989), Tech Rev p. 1. See also Kingsley Moghalu, 'Nigeria Gets Tough on Toxic Dumping, (1989)' Christian Science Monitor, p. 6.

${ }_{7}$ See Atteh, 'Political Economy of Environmental Degradation' p. 283.

68 See Brooke, 'Waste Dumpers Turning to West Africa'.

69 See Amnesty International and Greenpeace, 'The Toxic Truth', 9, 25 September 2012, [hereinafter The Toxic Truth] available at www.greenpeace.org/international/Global/ international/publications/toxics/ProboKoala/The-Toxic-Truth.pdf. 
contractor of Trafigua disposed of the waste at approximately eighteen openair sites in and around the city of Abidjan. ${ }^{70}$ Similar to the hazardous dumping incident in Nigeria, the ship attempted to discharge its waste in Europe, but was unable to, due to the toxicity of the waste. ${ }^{71}$ Following the toxic dumping in Abidjan, people living near the discharge sites began to suffer from a range of illnesses including: nausea, diarrhoea, vomiting, breathlessness, headaches, skin damage, and swollen stomachs. ${ }^{72}$ The exposure to this waste caused the death of sixteen people, and more than 100,000 people sought medical attention. ${ }^{73}$ Trafigura denied any wrongdoing. ${ }^{74}$ In early 2007 , the company paid approximately $\$ 195$ million for cleanup to the Ivorian government. ${ }^{75}$ The government waived its right to prosecute the company. ${ }^{76}$ Today, more than ten years after the dumping of large quantities of toxic waste in Côte d'Ivoire, despite the huge numbers of people affected, international coverage of the issue, and several legal proceedings, there remains no effective national, regional, or international mechanism to prevent and address a similar disaster. ${ }^{77}$

According to a three-year investigative report by Amnesty International and Greenpeace, 'too little has been done to strengthen national and international regulations, even after the scale of the toxic dumping became clear. ${ }^{{ }^{7}}{ }^{8}$ Greenpeace International Executive Director Kumi Naidoo stated that,

[Trafigura is] a story of corporate crime, human rights abuse and governments' failure to protect people and the environment. It is a story that exposes how systems for enforcing international law have failed to keep up with companies that operate transnationally, and how one company has been

70 See Environmental Justice Atlas, available online at http://ejatlas.org/conflict/toxic-wastedumping-in-abidjan-ivory-coast (last visited 3 March 2015).

${ }^{71}$ See Business and Human Rights Resource Centre, 'Trafigura Lawsuits' (re: Côte d'Ivoire), http://business-humanrights.org/en/trafigura-lawsuits-re-c\% $\mathrm{C}_{3} \% \mathrm{~B}_{4} \mathrm{te}-\mathrm{d} \% \mathrm{E}_{2} \% 80 \%$ g9ivoire (last visited 3 March 2015); see Amnesty International and Greenpeace International Press Release 25 September 2012, www.greenpeace.org/africa/en/Press-Centre-Hub/Press-releases/

AMNESTY-INTERNATIONAL_GREENPEACE-INTERNATIONAL-PRESS-RELEASE-/ (last visited 3 March 2015).

72 See The Toxic Truth supra p. 57.

73 See id. p. 10.

74 See id. p. 9; see also Bianca Lazzari, "The International Movement of Hazardous Waste: The Ivory Coast' 28 May 2014, https://prezi.com/ndibg6exyfij/the-international-movement-ofhazardous-waste-the-ivory-coa/ (last visited March 2015).

75 See The Toxic Truth supra p. 9.

$7^{6}$ See id.

77 For further discussion see Section 3.

$7^{8}$ See Fiona Harvey, 'Trafigura Lessons Have not Been Learned, Report Warns', The Guardian 25 September 2012, www.theguardian.com/environment/2012/sep/25/trafigura-lessons-toxicwaste-dumping. 
able to take full advantage of legal uncertainties and jurisdictional loopholes, with devastating consequences. ${ }^{79}$

The victims of Trafigura's toxic dumping in Côte d'Ivoire were not able to seek redress in their domestic judiciary. They had to seek justice in Europe, which ultimately proved unsatisfactory. ${ }^{80}$

The incidents of toxic colonialism discussed above indicate that several countries attempted to take steps to limit toxic dumping in their territories by resorting to criminal sanctions. ${ }^{81}$ These countries also utilized tort law, but both areas of their domestic law proved to be inadequate deterrents. The spate of toxic dumping that took place in the 1980s led the Organization of African Unity $(\mathrm{OAU}),{ }^{82}$ to pass a resolution urging all member states to ban all imports of waste chemicals, metals, and radioactive materials, calling the trafficking in hazardous waste a "crime against Africa and the African people. ${ }^{83}$ The OAU passed the resolution in 1988, shortly after the toxic dumping scandal in Nigeria had come to light. The Resolution condemned the dumping of hazardous waste by $\mathrm{MNCS}^{8}{ }^{4}$ and urged its members to stop arranging for waste dumping. ${ }^{85}$ It also sought to require that dumpers "clean up the areas that have already been contaminated by them.' ${ }^{86}$ Although a non-binding political statement, this Resolution would lay the foundation for the position that African states would adopt regarding the importing of hazardous waste from outside Africa. African countries' individual experiences with toxic colonialism are emblematic of why greater cooperation in regulating hazardous waste was needed. This section has also illustrated how the experience

79 Amnesty International, 'Report Slams Failure to Prevent Toxic Waste Dumpling in West Africa’ 25 September 2012, available at www.amnesty.org/en/articles/news/2012/og/report-slamsfailure-prevent-toxic-waste-dumping-west-africa/.

8० For further discussion of the case against Trafigura see e.g., Cyril Gwam, 'Symposium Powering the Future: A 21st Century Guide for Energy Practitioners: Human Rights Implications of Illicit Toxic Waste Dumping from Developing Countries Including the U.S.A., Especially Texas to Africa, in particular Nigeria' (2013), 38 Thurgood Marshall Law Review 241, 259-66; Holy Hall, 'Super-Injunction, What's Your Function' (2013), 18 Commercial Law and Policy 309, 320-2.

${ }^{81}$ See Chris Okeke, 'Africa and the Environment' (1996), 3 Annual Survey of International \& Comparative Law 37, 62.

82 The OAU 'steered Africa's political and ideological matters since its inception' in Abou Jeng, 'Peacebuilding in the African Union' p. 136.

83 Article 1 of the Organization of African Unity: Council of Ministers Resolution on Dumping of Nuclear and Industrial Waste in Africa, 23 May 1988, reprinted in 28 I.L.M. 568 (1989) [hereinafter OAU Resolution].

84 Id. art. 2.

85 Id. art. 3 .

86 Id. art. 2. 
with toxic colonialism on the Continent would later influence the decision to attempt to regionally criminalize the trafficking of hazardous waste in the Malabo Protocol.

\section{INTERNATIONAL LEGAL FRAMEWORK FOR REGULATING HAZARDOUS WASTE AND AFRICAN REGIONAL INNOVATION}

This section will explore how the inadequate international legal framework for regulating hazardous waste, led to the attempt to criminalize the trafficking in hazardous waste regionally in Africa. The intention here is not to provide a comprehensive analysis of the main shortcomings of this area of international law. ${ }^{87}$ Instead, this section briefly highlights the existing state of international law governing the import of hazardous waste and the control of transboundary movements of such wastes and analyzes African attempts to innovate regionally. This section demonstrates how African states have been at the forefront of efforts to penalize trafficking in hazardous waste - leading the way through a ban in a regional treaty, which would subsequently be reflected more generally in international law. African states once again are at the forefront of shaping international law in this area by moving to prosecute trafficking in hazardous waste through the Malabo Protocol.

\section{A. The Inadequate Legal Framework for Regulating Hazardous Waste}

This section provides much needed context on the international regulation of hazardous waste. The treaty governing this area, the Basel Convention of 1989, did not provide for a complete prohibition on the trafficking of hazardous waste. Consequently, African states insisted on such a ban in a regional treaty the Bamako Convention of 1991. To date, the international regime governing this area of law has not adopted the abolitionist position seen in the Bamako Convention. Efforts to change the international regime through an amendment to the Basel Convention (Basel Ban Amendment), which would adopt the African prohibition on hazardous waste rule globally have stalled due to the resistance of countries in the Global North. This stalemate at the international level regarding the prohibition on hazardous waste helps to explain in part why African States through the Malabo Protocol, are attempting to create

${ }^{87}$ For more on the limitations of the current legal framework see generally Robert Percival, 'Global Law and the Environment,' (2011) 86 Washington Law Review, 579; Frederic Megret, 'The Problem of an International Criminal Law of the Environment,' (2011) 36 Columbia Journal of Environmental Law 195 (2011); Pratt 'Decreasing Dirty Dumping?'. 
a regional forum for prosecuting the crime of trafficking in hazardous waste. Article 28L in the Malabo Protocol can only be understood against this background as it incorporates provisions articulated in the regional Bamako Convention of 1991.

\section{International Regulation through the Basel Convention of 1989}

The Basel Convention of 1989, which entered into force in 1992 is the primary international agreement for the regulation of hazardous waste. ${ }^{88}$ Prior to this treaty, the international regulation in this area consisted of non-binding softlaw. For example, in 1987 UNEP gathered a group of experts to develop an agreement for the 'environmentally sound management of hazardous waste,' which came to be known as the Cairo Guidelines. ${ }^{89}$ Global concerns regarding hazardous waste 'sparked a desire to create a more binding agreement' and led to the Basel Convention. ${ }^{\circ}$

The Basel Convention imposes certain general obligations on States Parties. These general obligations include ensuring that the generation of hazardous wastes within the State is 'reduced to a minimum, taking into account social, technological, and economic aspects. ${ }^{91}$ As of October 2018, 186 states are party to the Basel Convention. ${ }^{92}$ The Basel Convention works more like a trade regime - in that it seeks to control the movement of hazardous waste 'through a system of prior informed consent, strict notification, and tracking requirements. ${ }^{93}$ Under this system, the movement of hazardous waste is only permitted where the exporting country does not have the capacity to dispose of the material in an environmentally sound and efficient manner,' or the waste is required in the importing country as a raw material for recycling or recovery. ${ }^{94}$ The Basel Convention also requires certain notification between State Parties when hazardous wastes will be moved between or among them. To start, the State of export must notify the

88 Basel Convention on the Control of Transboundary Movements of Hazardous Waste and Their Disposal, Basel, 22 March 1989, in force 5 May 1992, 28 I.L.M. 649 also available at www.basel .int/Portals/4/Basel\%2oConvention/docs/text/BaselConventionText-e.pdf. [hereinafter Basel Convention].

89 UNEP, Cairo Guidelines and Principles for the Environmentally Sound Management of Hazardous Waste, 14/30 December, 17 June 1987 available at www.unep.org/Documents .multilingual/Default.asp?DocumentID $=100 \&$ ArticleID $=1663 \& \mathrm{l}=\mathrm{en}$.

$9 \circ$ Pratt 'Decreasing Dirty Dumping?' p. 158.

$9^{1}$ Art. 4(2) of the Basel Convention.

92 See Parties to the Basel Convention available at www.basel.int/Countries/ StatusofRatifications/PartiesSignatories/tabid/4499/Default.aspx (last visited 23 October 2018).

93 Id. at 160 . See also Art. 6 of the Basel Convention.

94 Art. 4(9) of the Basel Convention. See also Pratt ‘Decreasing Dirty Dumping?’ p. 160. 
State of import of any proposed transport of hazardous wastes. ${ }^{95}$ The State of import must then respond in writing, expressing its consent to the movement, denying permission for the movement, or requesting additional information..$^{6}$ The Convention also prohibits the transboundary movement of hazardous waste exported to a non-Party or imported from a non-Party. ${ }^{97}$

Article 9 provides that any transboundary movement of hazardous wastes or other wastes is considered 'illegal', if the movement occurs:

(a) without notification pursuant to the provisions of this Convention to all states concerned; or

(b) without the consent pursuant to the provisions of this Convention of a State concerned; or

(c) with consent obtained from States concerned through falsification, misrepresentation or fraud; or

(d) [in a manner] that does not conform in a material way with the documents; or

(e) [in a manner] that results in deliberate disposal (e.g.) dumping of hazardous wastes or other wastes in contravention of this Convention and of general principles of international law..$^{8}$

In the event of illegal trafficking in hazardous waste the Basel Convention provides depending on fault that the exporter or generating state take back the waste if practicable or otherwise dispose of it. ${ }^{99}$ Where the importer or the disposing state is found to be at fault, then that state is responsible for disposal in an environmentally safe manner; and where it is unclear who is at fault amongst the parties, then the Convention provides that the parties are to cooperate to make sure that the waste is disposed of in an environmentally sound manner. ${ }^{100}$ Rather than seeking enforcement through an international or regional court, the Basel Convention provides that each party shall introduce appropriate national/domestic legislation to prevent and punish illegal trafficking. ${ }^{101}$ The parties to the Basel Convention envisioned that enforcement would take place through a tort-law regime. ${ }^{102}$ They subsequently enacted a Protocol setting out appropriate rules and procedures for liability and compensation for damage resulting from the transboundary movement

95 See Art. 6(1) of the Basel Convention.

$9^{6}$ Id. art. 6(2).

97 Id. art. 4(5).

$9^{8}$ Id. art. 9(1).

99 Id. art $9(2)$.

${ }^{100}$ Id. art $9(2)$.

${ }^{101}$ Id. art. 9(5).

${ }^{102}$ Id. art. 12. 
and disposal of hazardous wastes and other wastes. ${ }^{103}$ The Basel Convention does not provide for prosecutions of traffickers of hazardous waste through an international or transnational court like that Malabo Protocol envisions.

\section{Other Attempts at International Regulation of Hazardous Waste}

The Basel Convention has been followed by other subsequent agreements and amendments, which continue to shape the international regulation of hazardous waste. For example, African, Caribbean (ACP) states signed the Lomé IV Convention in 1990 with the European Economic Community. ${ }^{104}$ The Lomé IV Convention prohibited the export of hazardous waste from the European Community to ACP States, and in return the ACP states agreed not to accept waste from any country outside of the European Community. ${ }^{105}$ The agreement between the ACP states noted that in interpreting the provisions of the ban it would be guided by the principles and provisions in an $1988 \mathrm{OAU}$ Resolution, ${ }^{106}$ which amongst others considered the trafficking in hazardous waste to be a 'crime against Africa and the African people.' ${ }^{\text {'07 }}$ The Lomé IV Convention expired in 2000. ${ }^{108}$

Overlapping regimes can result in a "race to the bottom" seeking lower barriers to entry. That is instead of states deciding to bind themselves to higher obligations, states can seek to lower their obligations. The Cotonou Agreement, which replaced the Lomé IV Convention between the European Community and ACP states in 2000 illustrates this point. ${ }^{110}$ The Cotonou Agreement backtracks from the hazardous waste ban contained in

${ }^{103}$ See Basel Protocol on Liability and Compensation for Damage Resulting from Transboundary Movements of Hazardous Waste and their Disposal, 10 December 1999, in force 27 May 2014 available at www.basel.int/Portals/4/Basel\%2oConvention/docs/text/ BaselConventionText-e.pdf. [hereinafter Basel Protocol].

104 See The Fourth African, Caribbean, and Pacific States - European Economic Community Convention of Lomé, Lome, 22 March 1990, 29 I.L.M. 783 available at http://aei.pitt.edu/4220/ 1/4220.pdf [hereinafter Lomé IV Convention].

105 Art. 39 of the Lomé IV Convention.

${ }^{106}$ Annex VIII of the Lomé IV Convention, Joint Declaration on Article 39 on Movements of Hazardous Waste or Radioactive Waste.

107 OAU Resolution.

108 See Pratt 'Decreasing Dirty Dumping?’ p. 166.

109 Kenneth W. Abbott, The Transnational Regime Complex for Climate Change, 30 Environment and Planning C: Government \& Policy 584 (2012) (discussing how this can lead to "pathological effects of unnecessary fragmentation").

${ }^{110}$ See generally Partnership Agreement between the Members of the African, Caribbean and Pacific Group of States of the One Part, and the European Community and Its Member States, of the Other Part, 2000 O.J. (L 317) 3 (entered into force 4 January 2003) [hereinafter Cotonou Agreement] available at https://ec.europa.eu/europeaid/sites/devco/files/cotonou-agreement2000_en.pdf. 
the Lomé IV Agreement. Instead, the Agreement takes "into account issues relating to the transport and disposal of hazardous wastes." ${ }^{\prime 11}$ Without the total ban, the Cotonou Agreement is significantly weakened. ${ }^{112}$ African states have attempted to improve upon these attempts at regulating hazardous waste.

2. Regional Innovation and Regulation of Hazardous Waste through Bamako Convention of 1991

Significantly, the OAU expanded on its 1988 Resolution and adopted the Bamako Convention in 1991, which created a regional ban on the importation of all hazardous waste into Africa and limits the transfer of hazardous waste within Africa. ${ }^{113}$ The Bamako Convention entered into force in 1998 and imposes a duty on states to take legal, administrative, and other measures to prohibit the import of any hazardous wastes into their territories. ${ }^{114}$ Moreover, the Convention stipulates that any importation of hazardous waste into Africa, 'shall be deemed illegal and a criminal act."'15 This was a pointed development from the Basel Convention, which considered trafficking 'illegal,' but not criminal. ${ }^{116}$ The Bamako Convention also imposes, 'strict, unlimited liability as well as joint and several liability on hazardous waste generators. ${ }^{117}$ This was another important improvement over the Basel Convention, which did not stipulate the rules for liability within the Convention. ${ }^{118}$ With respect to hazardous waste generated within Africa, the Convention mimics the Basel Convention provisions. ${ }^{119}$ As of October 2018, the Bamako Convention had twenty-nine signatories, and twenty-five parties. ${ }^{120}$

${ }^{111}$ Id. art. $32(1)(d)$.

${ }^{112}$ See Pratt 'Decreasing Dirty Dumping?' p. 166.

${ }^{113}$ See generally Bamako Convention.

${ }^{114}$ Art. 4 of the Bamako Convention.

${ }^{115} \mathrm{Id}$.

${ }^{116}$ See Art. 9 of the Basel Convention.

${ }^{117}$ Art. 4(3)(b) of the Bamako Convention; Art. 1(20) of the Bamako Convention defining a waste generator as 'any person whose activity produces hazardous wastes, or, if that person is not known, the person who is in possession and/or control of those wastes'.

${ }^{118}$ See Art. 12 of the Basel Convention.

${ }^{119}$ See Art. 11 of the Bamako Convention (For intra-African waste trade, parties must minimize the transboundary movement of wastes and only conduct it with consent of the importing and transit states among other controls. Parties are to minimize the production of hazardous wastes and cooperate to ensure that wastes are treated and disposed of in an environmentally sound manner.

${ }^{120}$ See Parties to the Bamako Convention www.unenvironment.org/events/conference/secondconference-parties-bamako-convention (last visited 11 March 2018). 
The Bamako Convention parallels the Basel Convention, with some important distinctions. The Bamako Convention, like the Basel Convention, imposes certain general obligations on States Parties, ${ }^{121}$ but as indicated above, the Bamako Convention imposes significantly more aggressive obligations. OAU member states were dissatisfied with the Basel Convention, which does not explicitly ban the export of hazardous waste. ${ }^{122}$ Accordingly, almost all OAU countries except for Nigeria, refused to ratify the initial Basel Convention. ${ }^{123}$ Recall that the Basel Convention has a limited ban on exports and imports of hazardous waste to and from non-parties to the Convention. ${ }^{124}$ Thus, one of the key motivations for the creation of the African regional convention was the failure of the Basel Convention to ban imports of hazardous waste from more developed countries into less developed ones. Consequently, the first general obligation imposed by the Bamako Convention is a hazardous waste import ban, which states in part, '[a]ll Parties shall take appropriate legal, administrative and other measures within the area under their jurisdiction to prohibit the import of all hazardous wastes, for any reason, into Africa from non-Contracting Parties... ${ }^{125}$

The Basel and Bamako Conventions in many ways reflect the split between the Global North and South in the regulation of hazardous waste - with the Global North favouring a free-trade model for hazardous waste, and the Global South demanding a total ban on toxic waste. ${ }^{126}$ Both views emanate from concerns over enforcement - with the Global North viewing a total ban as impossible to enforce, and the Global South viewing the free-trade model as impossible to monitor or control effectively due to disparities in technological and environmental infrastructure. ${ }^{127}$ The Global South's view was reinforced by the series of toxic dumping scandals that took place in Africa even after the Basel Convention came into force. ${ }^{128}$ This may also help to explain why the scope of what constitutes hazardous waste in the Bamako Convention is much wider, than what the Basel Convention covers. ${ }^{129}$

${ }^{121}$ Art. 4 of the Bamako Convention.

${ }^{122}$ See Jennifer R. Kitt, 'Note, Waste Exports to the Developing World: A Global Response’ (1995), 7 Georgetown Environmental Law Review 485, 500-1.

${ }^{123} \mathrm{See} \mathrm{Vu}$, 'The Law of Treaties and the Export of Hazardous Waste' p. 410.

${ }^{124}$ See Art. 4(5) of the Basel Convention.

125 Art. 4(1) of the Bamako Convention.

${ }^{126}$ See Atteh, 'Political Economy of Environmental Degradation' p. 283.

127 See id.

${ }^{128}$ See Section $2 \mathrm{~B}$ of this Chapter.

129 Compare art. 1, Annex I and Annex II of the Basel Convention, with art. 7, annex I and annex II of the Bamako Convention. The Bamako Convention not only includes radioactive wastes, but also considers any waste with a listed hazardous characteristic or a listed constituent as a 
Crucially, the Bamako Convention also provides that the import of hazardous waste, 'shall be deemed illegal and a criminal act.' ${ }^{130}$ Like the Basel Convention, the Bamako Convention also contains a section on the illegality of trafficking in hazardous waste. ${ }^{131}$ While the Bamako Convention reiterates the five conditions of illegality, quoted above in the Basel Convention the Bamako Convention goes much further. It stipulates that, "[e]ach Party shall introduce appropriate national legislation for imposing criminal penalties on all persons who have planned, committed, or assisted in such illegal imports. Such penalties shall be sufficiently high to both punish and deter such conduct.' ${ }^{132}$ As such, the Bamako Convention envisions that trafficking in hazardous waste will be regulated not simply through a tort-law regime like the Basel Convention, but crucially through each state's domestic penal law. Thus, the Bamako Convention provides a clear rationale to understand the later move to create a regional forum to prosecute the trafficking of hazardous waste in the Malabo Protocol. It is likely that parties found that only relying on domestic enforcement to prosecute trafficking in hazardous waste was leading to insufficient punishment and deterrence and likely anticipated that the creation of a regional court through the Malabo Protocol would lead to better results.

\section{From Regional Innovation through Bamako to Attempts to Strengthen the International Regulatory Framework through Basel}

Moreover, the overlapping Bamako and Basel regimes for regulating trafficking in hazardous waste led to generative outcomes for the progressive development of international law. Some scholars have postulated that competing regimes can 'generate positive feedback: providing incentives for a "race to the top." 133 This occurs where countries take stronger action on a given issue in one regime, which generates imitation by others. ${ }^{134}$ An excellent example of this is how the Bamako Convention's imposition of strict liability on 'hazardous waste generators'135 influenced the Basel

hazardous waste. The Convention also covers national definitions of hazardous waste. Finally, products that are banned, severely restricted, or have been the subject of prohibitions, are also covered under the Convention as wastes.

${ }^{130}$ Art. 4(1) of the Bamako Convention.

${ }^{131}$ Compare Art. 9 of the Basel Convention with Article 9 of the Bamako Convention.

${ }^{132}$ Art. 9(2) of the Bamako Convention.

133 Robert O. Keohane and David G. Victor, 'The Regime Complex for Climate Change' (2011), 9

'Perspective on Politics' 19.

134 See id.

135 Art. 4(3)(b) and art. 1(20) of the Bamako Convention. 
Convention's Protocol on Liability and Compensation. ${ }^{136}$ Recall, the Bamako Convention entered into force in 1998, ${ }^{137}$ while the Basel Convention required parties to create and adopt a protocol on liability in 1989. ${ }^{138}$ The Basel Protocol was only adopted after heated negotiations in December of 1999. ${ }^{139}$ The Basel Protocol provides for strict liability for damages where parties to the Convention maintain control of the hazardous waste, but any person can also be subject to fault-based liability under the general principles of tort law. ${ }^{140}$ The Protocol needs twenty ratifications to enter into force, and as of October 2018, only had eleven ratifications. ${ }^{141}$ The stalled efforts at ratification reflects the continued split between the Global North and South on the regulation of hazardous waste.

Another instance of how the Bamako Convention is influencing international law regulating hazardous waste is the Basel Ban Amendment. ${ }^{12}$ In 1995, state parties to the Basel Convention decided by consensus that a total ban of hazardous waste should be developed. ${ }^{43}$ The Ban Amendment would go further than the Bamako Convention by prohibiting all exports of hazardous wastes between developed and developing countries, not just exports and imports within Africa like the Bamako Convention. ${ }^{144}$ The Ban Amendment technically needs sixty-two ratifications to come into effect. ${ }^{145}$ And as of October 2018, ninety-five parties have ratified the Ban, yet the amendment has still not entered into force. ${ }^{146}$ Countries have failed to reach agreement on how the provisions relating to amendment of the Basel Convention should be

\footnotetext{
${ }^{136}$ See generally Basel Protocol.

137 See Bamako Convention.

${ }^{13} 8$ See art. 12 of the Basel Convention.

139 See Pratt pp. 163-4.

${ }^{140}$ See arts. 4 and 5 of the Basel Convention.

${ }^{141}$ See List of Parties and Signatories to Basel Protocol available at www.basel.int/Countries/ StatusofRatifications/TheProtocol/tabid/1345/Default.aspx.

${ }^{142}$ See Decision III/1 Amendment to the Basel Convention, Third Meeting of the Conference of the Parties to the Basel Convention on the Control of Transboundary Shipments of Hazardous Waste and Their Disposal, September 18-22, 1995, UN Doc. UNEP/CHW.3/35.

143 The eighty-two parties present at the Third Meeting of the Conference of the Parties of the Basel Convention adopted the decision by consensus on 22 September, 1995. Id. See also art. $4 \mathrm{~A}$ and Annex VII of the Basel Convention [hereinafter Ban Amendment].

144 Id. Compare with Bamako Convention.

${ }^{145}$ See art. $17(5)$ of the Basel Convention which provides that amendments enter into force between the parties when 'at least three-fourths of the Parties who accepted them ratify the amendment. See also Pratt, 'Decreasing Dirty Dumping?’ p. 163 noting that sixty-two ratifications represent three-fourths of the parties present at the Third Meeting of the Conference of the Parties.

${ }^{146}$ See Parties to the Ban Amendment, available at www.basel.int/Countries/StatusofRatifications/ BanAmendment/tabid/1344/Default.aspx (last visited 23 October 2018).
} 
interpreted. ${ }^{147}$ In 2011, state parties agreed that the Ban Amendment will enter into force when three-fourths of those parties that were parties at the time of the adoption of the amendment ratify it. ${ }^{14^{8}}$ Countries in the Global South and Global North have continued to be split on the need and utility of a total ban on hazardous waste. Because the Basel Convention is a compromise document, the basic obligations under the treaty regime had to be lower in order to get more state parties to join the regime. ${ }^{149}$ The delayed efforts at getting a harder enforcement regime in place under the Basel Convention, provides additional normative justification for the Malabo Protocol's move to create a regional court to prosecute traffickers of hazardous waste.

Currently, the only international agreement, which bans the import of hazardous waste is the Bamako Convention. The rest of the international agreements in this area seek to put varying levels of control on the transboundary movements of such wastes. In sum, since tougher international action on trafficking in hazardous waste has been lacking, the need for African states to act regionally to create a venue for penalizing and punishing bad actors under the Malabo Protocol has only been reinforced. The African innovation in the field of environmental and criminal law is like how regional systems have demonstrated creativity and flexibility elsewhere. For example, regional systems have demonstrated creativity and flexibility in other areas of law by adopting regional human rights treaties to fill the gaps in international law. ${ }^{150}$ Regional systems also innovated to cover rights and duties not recognized in the main international human rights treaties. ${ }^{151}$ The regional human rights system has functioned to strengthen the enforcement of human rights across the globe and fill in gaps that the international system alone cannot

${ }^{147}$ For further discussion see Overview Basel Convention Ban Amendment available at www.basel.int/Implementation/LegalMatters/BanAmendment/Overview/tabid/1484/Default .aspx (last visited 23 October 2018).

${ }^{148}$ See id.

149 See Pratt 'Decreasing Dirty Dumping?' p. 163 discussing how the option of a total ban was tabled until future conferences of the parties.

${ }^{150}$ See e.g. Chaloki Beyani, 'Reconstituting the Universal: Human Rights as a Regional Idea' (2012), Cambridge Companion to Human Rights Law, 176.

${ }^{151}$ Compare the concept of peoples' rights in the African Charter on Human and Peoples' Rights, 27 June 1981, in force 21 October 19861520 U.N.T.S. 217 and concept of duties in the American Declaration of the Rights and Duties of Man, 2 May 1948, OEA/Ser.L.N.II.23, doc. 21, rev. 6 reprinted in Basic Documents Pertaining to Human Rights in the Inter-American System, OEA/Ser.L.V./II.82, doc. 6, rev. 1 at 1 with the omission of these concepts from the Universal Declaration of Human Rights, 10 December 1948 G.A. Res. 217 (III) A, UN Doc. A/RES/217 (III), International Covenant on Civil and Political Rights, 16 December 1966, S. Exec. Rep. 102-23, 999 U.N.T.S. 171 and the International Covenant on Economic, Social and Cultural Rights, 16 December 1966, S. Treaty Doc. No. 95-19, 6 I.L.M. 360 (1967), 993 U.N.T.S. 3. 
accommodate. ${ }^{152}$ Given the experience of regionalization in the international human rights regime, a similar outcome may pertain in the fields of international environmental and criminal law.

The regional criminalization of hazardous waste in the Bamako Convention allows for more regulation than was possible at the global level. The international regime created by the Basel Convention does not provide for any enforcement mechanisms for illegal trafficking. Instead, it provides that parties should adopt domestic legislation for the prevention and punishment of trafficking in hazardous waste. ${ }^{153}$ Since the OAU resolution in 1988, African states have considered the trafficking in hazardous waste to be a "criminal act'. ${ }^{154}$ This view was encapsulated in the Bamako Convention provision that states should adopt national laws to impose criminal penalties 'on all persons who have planned, committed, or assisted' in the illegal trafficking in hazardous waste. ${ }^{155}$ These penalties were to be 'sufficiently high to both punish and deter such conduct.' ${ }^{156}$ The analysis above has shown that despite the strong provisions of the Bamako Convention, ${ }^{157}$ the state parties to Bamako simply lacked the capacity to effectively enforce the provisions domestically and prevent toxic colonialism within their borders. ${ }^{158}$ Indeed, none of the international legal agreements discussed above have contained the illegal trade in hazardous waste, which is often transported under false pretences. ${ }^{159}$ Certainly, no state has the ability to check and inspect each shipment that enters its port to see, if it contains hazardous waste. ${ }^{160}$ Notwithstanding the widespread capacity limitations on an individual state level, the Malabo Protocol provides a potentially more robust venue for the regional prosecutions of trafficking in hazardous waste.

Article 28L of the Malabo Protocol is derived from longstanding efforts by African states to criminalize and punish trafficking in hazardous waste. Certainly, the Bamako Convention envisioned future regional agreements regarding the transboundary movement and management of hazardous wastes

${ }^{152}$ See Beyani 'Reconstituting the Universal: Human Rights as a Regional Idea' p. 190;

George William Mugwanya, 'Realizing Universal Human Rights Norms through Regional

Human Rights Mechanisms: Reinvigorating the African System’ (1999), 10 Indiana

International \& Comparative Law Review 35, 40.

153 See art. 4(5) of the Basel Convention.

154 See the OAU Resolution.

${ }^{155}$ See art 9(2) of the Bamako Convention.

${ }^{156} \mathrm{Id}$.

157 See art 4 of the Bamako Convention.

${ }^{15}$ See Section $2 \mathrm{~B}$ of this chapter.

159 See Pratt 'Decreasing Dirty Dumping?' p. 167.

${ }^{160}$ Id. pp. 167 and 173. 
generated in Africa and allowed for such arrangements so long as they 'do not derogate from the environmentally sound management of hazardous wastes as required' by Bamako and are 'no less environmentally sound than those provided for' under the Bamako Convention. ${ }^{161}$ Article $28 \mathrm{~L}$ of the Malabo Protocol is consistent with the Bamako Convention and promotes 'SouthSouth co-operation in the implementation of the Convention'162 through the creation of a regional forum for prosecutions of traffickers of hazardous waste amongst others.

\section{B. African Regional Innovation and Enforcement through Malabo}

This section discusses some of the legal and practical challenges that might arise with the enforcement of article 28L. Under the Bamako Convention, state parties were urged to cooperate and consider other 'enforcement mechanisms' to ensure that no imports of hazardous waste enter Africa. ${ }^{163}$ The Malabo Protocol is potentially such an enforcement mechanism - it creates a regional venue for prosecuting trafficking in hazardous waste, amongst other crimes. The Protocol improves upon the international framework for regulating the trafficking of hazardous waste. Article 28L of the Malabo Protocol provides that 'any import, or failure to re-import transboundary movement or export hazardous waste proscribed by the Bamako Convention ... shall constitute the offence of trafficking in hazardous waste' and fall under the criminal jurisdiction of the regional court. ${ }^{164}$ Yet, there are several uncertainties as to how Article 28L should be interpreted. Moreover, there are a host of political, financial, and other obstacles that may impede the regional criminal court's ability to offer a robust prosecution mechanism for the trafficking in hazardous waste. The sub-sections below discuss both issues in turn.

\section{Interpretative Challenges}

Article $28 \mathrm{~L}$ potentially invites confusion as it requires reference to a separate legal text to determine the relevant criminal prohibitions. When one turns to the Bamako Convention, article 1(22) informs the reader that illegal trafficking 'means any transboundary movement of hazardous wastes as specified in article 9 of this Convention. ${ }^{165}$ Article 9(2) provides for the criminal penalties

\footnotetext{
${ }^{161}$ Art. 11(1) of the Bamako Convention.

${ }_{162}$ Id. art. $11(4)$.

163 See Art. 4(1)(b) of the Bamako Convention.

${ }_{164}$ Art. 28L of the Malabo Protocol.

165 Art. 1(22) of the Bamako Convention.
} 
to be imposed on 'all persons who have planned, committed, or assisted' in illegal trafficking in hazardous waste. ${ }^{166}$ This occurs according to article 9(1), when transboundary movement of waste occurs without notification or without consent of the relevant state, when consent is obtained through falsification, misrepresentation, or fraud, and when the waste does not conform materially with the documents. ${ }^{167}$ While it might have been possible to interpret article $28 \mathrm{~L}$ of Malabo such that it could cover only those offences that the Bamako Convention itself says are criminal acts under article 9, this interpretative methodology is unavailable because of the broad scope of the language in the last provision. Article $9(1)(\mathrm{e})$ stipulates criminal penalties when hazardous waste is deliberately disposed of in contravention of the Convention and of the general principles of international law. ${ }^{, 168}$

Article 9(1)(e) of the Bamako Convention is the most ambiguous in terms of figuring out the scope of criminal liability under article $28 \mathrm{~L}$ of the Malabo Protocol. For one, it is not exactly clear what general principles article 9(1) (e) refers to. And, as discussed above, the general international law framework for regulating hazardous waste does not attach criminal penalties to trafficking in hazardous waste. Moreover, there are numerous ways to dispose of hazardous waste in 'contravention' of Bamako. While article 4(1) of the Bamako Convention clearly makes importing hazardous waste into Africa an illegal and criminal act, it is not evident that all of the obligations that states undertook in Bamako were to also have that effect. ${ }^{169}$ For example, article 4(2) of the Bamako Convention, which bans the dumping of hazardous waste at sea and in internal waters, specifies that all such actions shall be illegal, but does not contain the same 'and a criminal act' of article 4(1)'s prohibition. ${ }^{170}$ Thus, it is unclear whether the Malabo Protocol wishes to expand Bamako to criminalize trafficking in hazardous waste at sea and in internal waters.

In addition, the Bamako Convention contains a host of very detailed obligations that state parties undertook for the transportation of hazardous waste within Africa. ${ }^{171}$ With some of these provisions - such as Bamako's expansive definition of what constitutes 'hazardous waste' - it is apparent that the Malabo Protocol sought to include them within the criminal

\footnotetext{
${ }^{166}$ Id. art. 9(2).

${ }^{167}$ Id. art. $9(1)(a)-(d)$.

${ }^{168}$ Id. art. $9(1)(\mathrm{e})$.

${ }^{169}$ Id. arts. 4(1) and $4(2)$.

${ }^{170}$ Id.

${ }^{171}$ Id. art. 4(3)(i)-(u).
} 
jurisdiction of the court. ${ }^{12}$ However, for other obligations, like parties agreeing "not to allow the export of hazardous wastes for disposal within the area South of 60 degrees South Latitude, ${ }^{173}$ it is not as straightforward. Additionally, the Bamako Convention contains detailed rules about the specific form and timing of notifications to be exchanged prior to the transportation of hazardous wastes across borders. ${ }^{174}$ It would seem nonsensical to impose criminal liability for transportation of wastes that do not conform to every single provision in the Convention. Moreover, this is likely not what the drafters of Malabo intended. Yet it is certainly possible to interpret article $28 \mathrm{~L}$ quite broadly - to criminalize any violation of any rule or regulation contained in the Bamako Convention governing the transportation of hazardous waste across state boundaries. Accordingly, it would be helpful if state parties further clarified what exactly was being criminalized so that actors can be aware of the permissible and impermissible bounds of conduct. Moreover, this would help ensure that the court's resources are used judiciously, and that valuable time is not spent prosecuting minor violations of the Bamako Convention that the Malabo Protocol drafters did not intend to criminalize nor dedicate resources towards the regional prosecution of these offences.

The analysis above indicates that the Protocol needs to be much clearer about what specifically is being made illegal and criminalized. The Bamako Convention sets out many detailed rules relating to the transport of waste. It seems unreasonable to impose criminal liability for transport of wastes that do not conform with every single provision in the Convention. Accordingly, much more clarification is needed. This is important because it potentially violates one of the bedrock principles of criminal justice - legality. Individuals need to be given fair warning and notice about the criminal laws such that they can conform their conduct with the dictates of the law. In short, the Protocol would benefit from a clear statement of which 'proscribed' practices it is making illegal.

${ }^{172}$ Compare Art. 28L(2) of the Malabo Protocol with Arts. 2 and 4(3)(i) of the Bamako

Convention. Bamako not only includes radioactive wastes, but also considers any waste with a listed hazardous characteristic or a listed constituent as a hazardous waste. The Convention also covers national definitions of hazardous waste. Finally, products that are banned, severely restricted, or have been the subject of prohibitions, are also covered under the Convention as wastes to be criminally prohibited from importation into Africa. Id.

${ }_{173}$ Art. 4(3)(1) of the Bamako Convention.

${ }^{174}$ Id. art. 6. 


\section{Practical Challenges}

The regional court's expansive jurisdiction might assist with more effective prosecutions of toxic dumping incidents. When the Protocol enters into force, the Court can exercise jurisdiction over trafficking in hazardous waste and other crimes committed after that date. ${ }^{175}$ The Assembly of the Heads of State and Government, and the Peace and Security Council ${ }^{176}$ of the AU, as well as State parties, and the independent prosecutor $^{177}$ will be able to submit cases to the Court. ${ }^{178}$ The Court can only exercise its jurisdiction where a State accepts its jurisdiction, where the crime was committed on the territory of the State, where the accused or victim is a national of the state, and when the vital interests of a state are threatened by the extraterritorial acts of non-nationals. ${ }^{179}$ The Court does not have jurisdiction over persons under the age of eighteen during the alleged commission of the crime. ${ }^{180}$ The Court's provision for corporate criminal liability ${ }^{181}$ will be important in prosecutions of traffickers. Controversially, the Court does not have jurisdiction over any 'serving AU Head of State or Government, or anybody acting or entitled to act in such capacity, or other senior state officials based on their functions, during their tenure of office. ${ }^{182}$ This immunities provision is in stark contrast with the statutes of other international criminal tribunals. ${ }^{183}$ It has caused significant backlash towards the court from scholars and practitioners. ${ }^{184}$ This chapter discusses some of the challenges raised by the

175 See art. $46 \mathrm{E}$ of the Malabo Protocol.

${ }^{176}$ See art. 2 of the Protocol Relating to the Establishment of the Peace and Security Council of the African Union, Durban, 9 July 2002), www.au.int/en/sites/default/files/Protocol_peace_ and_security.pdf) [hereinafter PSC Protocol] establishing the PSC as the permanent mechanism for conflict prevention and resolution on the Continent.

${ }^{177}$ See art. 46G of the Malabo Protocol.

${ }^{178}$ See art. 15 of the Malabo Protocol.

${ }^{179}$ See art. 46E of the Malabo Protocol.

${ }^{180}$ See art. 46D of the Malabo Protocol.

${ }^{181}$ See. art. 46C of the Malabo Protocol.

${ }^{182}$ Art. $46 \mathrm{~A}$ bis of the Malabo Protocol.

${ }^{183}$ See art. 27 Rome Statute supra note 5, detailing the irrelevance of official capacity for exempting someone from criminal responsibility; Art. 6 of the ICTR Statute; Art. 7 of the ICTY Statute; Art. 6 of the SCSL Statute.

${ }^{18} 4$ See e.g., Mark Kersten, 'What Gives? African Union Head of State Immunity', Justice in Conflict' 7 July 2014), available at http://justiceinconflict.org/2014/07/o7/what-gives-africanunion-head-of-state-immunity/; MireilleAffa'a-Mindzie, 'Leaders Agree on Immunity for themselves during Expansion of African Court', IPI Global Observatory, 23 July 2014, available at http://theglobalobservatory.org/2014/o7/leaders-agree-immunity-expansion-african-court/. 
corporate criminal liability and immunity provisions for prosecuting traffickers of hazardous waste below. ${ }^{185}$

Further, there are myriad financial, political and other obstacles that will likely hinder the Court's ability to function effectively and mount prosecutions against traffickers in hazardous waste, if they are not addressed. First, once established, it is likely that the Court will face challenges regarding political will to enforce decisions. It is also likely, that the regional criminal Court will face credibility issues because of the issue of official immunity. Moreover, the Court will likely have difficulty guarding against bias accusations, particularly when the individuals or entities are from outside of the African region. Additionally, the Court will probably encounter challenges ensuring adequate funding, meeting international fair trial standards and conducting its proceedings with sufficient transparency. Furthermore, the Court may suffer from less judicial and lawyering experience than exists at the international level. Notwithstanding these logistical and conceptual concerns, the Malabo Protocol's criminalization and provision of a common forum for prosecutions for the trafficking of hazardous waste, ${ }^{186}$ pushes the boundaries of international environmental and criminal law in a much-needed direction. In essence, the failure of both domestic and international institutions to effectively deal with trafficking in hazardous waste, has created a space for African states to innovate and attempt to change the status quo by utilizing a regional institution to criminalize and prosecute trafficking in hazardous waste.

\section{IMPLICATIONS OF CRIMINALIZING AND PROSECUTING HAZARDOUS WASTE REGIONALLY}

Recollecting that the Bamako Convention called for the imposition of criminal penalties domestically, and that said penalties 'shall be sufficiently high to both punish and deter' trafficking in hazardous waste. ${ }^{187}$ Further, the Bamako Convention requires that Parties to the Convention 'co-operate with one another and with relevant African organisations, to improve and achieve the environmentally sound management of hazardous wastes. ${ }^{188}$ Because the Bamako Convention laid the groundwork for Article 28L, this section analyzes whether Article 28L furthers the criminal prosecution objectives of the Bamako

\footnotetext{
${ }^{185}$ See Section 4. For further discussion see Sirleaf, 'Regionalism, Regime Complexes and International Criminal Justice in Africa'.

${ }^{186}$ See art. 28L of the Malabo Protocol.

${ }^{187}$ Art. 9(2) of the Bamako Convention.

${ }^{188}$ Id. art. $10(1)$.
} 
Convention. It does this by analyzing the potential implications of criminalizing and prosecuting trafficking in hazardous waste regionally through the Malabo Protocol. This section also considers whether the regional prosecution of trafficking in hazardous waste contributes towards some of the newer theories of punishment like restorative justice and expressive condemnation, as well as some of the more traditional goals of punishment like retribution and deterrence. Lastly, this section examines how some of the more pressing challenges might be resolved through creative interpretation of the Protocol to assist with furthering the sound regulation of hazardous wastes.

\section{A. Regional Criminalization of Trafficking in Hazardous Waste and Retributive Justice}

How should the traditional notions of criminal law, based as they are on the idea of a natural person capable of criminal and actions, be applied to corporations deemed responsible for illegal dumping? Further, how can we think of the regional prosecution of trafficking in hazardous waste in relation to its ability to further retribution? Retributive justice theories of punishment emanated from the desire for vengeance and 'just deserts' for offenders. ${ }^{189}$ Most modern retributivists, however, reject the notion of an 'eye for [an] eye,' and instead seek to determine the degree of punishment in relation to the magnitude of the alleged crimes. ${ }^{190}$ The Malabo Protocol allows for the imposition of prison sentences, pecuniary fines, and forfeiture of property acquired unlawfully. ${ }^{191}$ The Protocol also stipulates that the regional Court should be guided by the "gravity of the offence and the individual circumstances of the convicted person.' ${ }^{192}$ The analysis above indicates that states have provided for criminal sentences ranging from twenty years to life imprisonment and fines of up to $\$ 1.6$ million for trafficking in hazardous waste. ${ }^{193} \mathrm{It}$ is not clear how 'grave' the Court will determine the crime of trafficking in hazardous waste is, and whether this will comport with the sentences or fines

${ }^{189}$ See e.g. Immanuel Kant's Perpetual, Peace: 'A Philosophical Proposal', (London: Sweet \& Maxwell, Ltd, 1927); Susan Jacoby 'Wild Justice; The Evolution of Revenge’, (New York: Harper \& Row, 1983).

${ }^{190}$ Paul H. Robinson, 'Competing Conceptions of Modern Desert: Vengeful, Deontological, and Empirical’ (2008), 67 Cambridge Law Journal 145, 147; see also Allison Marston Danner, 'Constructing a Hierarchy of Crimes in International Criminal Law Sentencing' (2001), 87 Virginia Law Review, 415, 444; Andrew Von Hirsch \& Nils Jareborg, Gauging Criminal Harm: A Living-Standard Analysis' (1991), 11 Oxford Journal of Legal Studies 1, 2-3.

${ }^{191}$ Art. 43 A of the Malabo Protocol.

${ }_{192}$ Art $43 \mathrm{~A}(4)$ of the Malabo Protocol.

193 See Section 2 B. 
available domestically. If the regional Court's sentencing or penalties for those found guilty of trafficking in hazardous waste is significantly at variance with domestic norms, this could frustrate the ability of the regional court to further retributive justice goals. The Court might need to develop something akin to the 'margin of appreciation' doctrine used by the European Court of Human Rights, ${ }^{194}$ for sentencing and to make sure its judgments comport with the majority of state's practice in the region.

Furthermore, because the Malabo Protocol bars the prosecution of not only Heads of States, but also of 'senior state officials' based on their functions, ${ }^{195}$ leaders who are accused of trafficking in hazardous waste could not be investigated and prosecuted before the regional Court. This is a serious challenge to the Court's ability to fulfil retributive justice goals given the role that some African leaders have played in facilitating dumping of hazardous waste in their territories. ${ }^{196}$ Failure to prosecute all equally culpable individuals violates the retributive principles of just deserts, as well as the principle of proportionality that all like crimes should be treated the same.

The ability of the Court to contribute towards retributive justice goals may also be limited because it is dependent on member states for the enforcement of its sentences and fines. ${ }^{197}$ Complications could arise where an individual is sentenced or an entity is fined by the regional court for trafficking in hazardous waste, but no state indicates their willingness to accept and imprison the sentenced person, or give effect to the fine ordered by the Court. Moreover, the Malabo Protocol also provides for the pardon or commutation of sentences, where a person convicted by the regional Court, would be eligible for a pardon or commutation in the jurisdiction where the convicted person is imprisoned. ${ }^{1{ }^{8}}$ In these circumstances, the regional court can issue a pardon or commutation of a sentence based on the interests of justice and the general principles of law. ${ }^{199}$ Depending on how the Court interprets these provisions, this could potentially allow for states to work around the attempt to criminalize and punish the trafficking in hazardous waste regionally. However, because the Malabo Protocol situates the regional criminal court within a

${ }^{194}$ See e.g., Paul L. McKaskle, "The European Court of Human Rights: What It Is, How it Works, and Its Future' (2005), 40 University of San Francisco Law Review 1, 49 explaining that the concept of margin appreciation allows for 'countries to differ in what is acceptable under the terms of the Convention based on cultural differences.'

${ }^{195}$ Art. 46 Abis of the Malabo Protocol.

${ }^{196}$ See Section $2 \mathrm{~B}$ of the chapter for further discussion.

197 See, arts. 46J and 46Jbis of the Malabo Protocol.

${ }^{198}$ Art $46 \mathrm{~K}$ of the Malabo Protocol.

199 Id. 
larger judicial architecture in the AU this can potentially be counteracted. Other relevant regional bodies that may assist with issues of compliance include the Panel of the Wise, the Peace and Security Council, and the African Standby Force. ${ }^{200}$ Of course, the existence of a connection with regional institutions does not completely deal with issues of non-compliance. ${ }^{201}$ For all of the reasons above, the regional prosecution of trafficking in hazardous waste may have limited ability to further retribution, which is a traditional goal of punishment and one of the Bamako Convention's objectives of punishing trafficking in hazardous waste.

Another concern is the court's ability to effectively exercise its control over offenders, especially offenders outside of the territory of any state party. Generally, hazardous waste moves from the Global North to South. Thus, although this will not necessarily always be the case, there is a high likelihood that violators importing waste will be coming from states that are not parties to the Protocol. The court may, thus, have a challenging time bringing offenders from the Global North before the Court for trial. For this reason, the Protocol's effectiveness and legitimacy could be enhanced by expanding the scope of its cooperation regime.

\section{B. Regional Criminalization of Trafficking in Hazardous Waste and Restorative Justice and Expressive Condemnation}

\section{Restorative Justice}

The prosecution of trafficking in hazardous waste through the regional court may help to further restorative justice goals. Restorative justice can be conceptualized as 'a process in which offenders, victims, their representatives and representatives of the community come together to agree on a response to a crime. $^{202}$ The overwhelming focus is to assist with 're-establishing social

${ }^{200}$ See arts. 7, 11, and ${ }_{13}(1)$ of the PSC Protocol providing the authority for the Peace and Security Council, establishing the Panel of the Wise, and providing for the African Standby Force; Arts. 3-4 of the AU Constitutive Act.

${ }^{201}$ George William Mugwanya, 'International Criminal Tribunals in Africa', in Mainsuli Ssenyonjo (ed.), The African Regional Human Rights System: zo Years after the African Charter on Human and Peoples' Rights (Leiden: Martinus Nijhoff Publishers, 2011) pp. 307-10. discussing the difficulties securing state cooperation with the criminal tribunals in Rwanda and Sierra Leone; see also Beyani, 'Reconstituting the Universal: Human Rights as a Regional Idea' p. 87 .

${ }^{202}$ Linda Gröning \& Jørn Jacobsen, 'Introduction: Restorative Justice and the Criminal Justice System', in Linda Gröning \& Jørn Jacobsen (eds.), 'Restorative Justice and Criminal Justice: Exploring the Relationship' (Sweden: Santerus Academic Press, 2012) pp. 9, 12. For further 
equilibrium'203 and facilitating 'corrective changes in the record, in relationships, and in future behavior. ${ }^{204}$ The regional court is empowered to provide compensation and reparation to victims. ${ }^{205}$ The Malabo Protocol also provides for the establishment of a trust fund for victims to provide legal aid and assistance. $^{206}$ The ability of the Court to contribute towards restorative justice goals may be limited, if the Court interprets these provisions narrowly. The Court's ability may also be limited, if the fund for victims is under-funded, or if reparations are administered in a problematic way. However, if the Court follows the lead of the Inter-American Court for Human Rights in fashioning remedies, it might order communal reparations, ${ }^{207}$ or formulate broad reparative and restorative measures ${ }^{208}$, which require the state to end the consequences of a violation through formulating specific policies and programmes. $^{209}$ There may also be insufficient compliance with restorative justice orders because of the Court's dependence on member states for enforcement. $^{210}$

discussion, see generally John Braithwaite, 'Narrative and "Compulsory Compassion”, (2006), ${ }_{31}$ Law E Social Inquiry: Journal of the American Bar Foundation 425 Elizabeth Kiss, 'Moral Ambition Within and Beyond Political Constraints: Reflections on Restorative Justice', in Robert I. Rotberg \& Dennis F. Thompson (eds.), 'Truth v. Justice: The Morality of the Truth Commissions' (New Jersey: Princeton University Press, 2000) pp. 68, 79-83.

${ }^{203}$ Jennie E. Burnet, '(In)Justice: Truth, Reconciliation, and Revenge in Rwanda’s Gacaca', in Alexander L. Hinton (ed.), Transitional Justice Global Mechanisms and Local Realities after Genocide and Mass Violence, (New Jersey: Rutgers University Press, 2011), pp. 95, 100.

${ }^{204}$ Martha Minow, 'Between Vengeance and Forgiveness: Facing History after Genocide and Mass Violence' (Boston: Beacon Press, 1999).

${ }^{205}$ See art. 20 of the Malabo Protocol.

${ }^{206}$ See art. $46 \mathrm{M}$ of the Malabo Protocol.

${ }^{207}$ See, e.g., Sawhoyamaxa Indigenous Community v. Paraguay, Merits, Reparations and Costs Judgment, Inter-Am. Ct. H.R. (ser. C) No. 146 (29 March 2006) The Court fashioned an order, which provided that the state was to allocate $\$ 1$ million to a community development fund for educational, housing agricultural, and health projects. In addition, the state was to provide compensation of $\$ 20,000$ each to the 17 members of the community who died because of events.

${ }^{208}$ For further discussion, see Thomas M. Antkowiak, 'An Emerging Mandate for International Courts: Victim-Centered Remedies and Restorative Justice' (2011), 47 Stanford Journal of International Law 279.

${ }^{209}$ See e.g. Miguel Castro Prison v. Peru Merits, Reparations and Costs Judgment, Inter-Am. Ct. H.R. (ser. C) No. 160 (25 November 2006) The Court's order provided amongst others that the state needed to carry out a public act of acknowledgement of its international responsibility in relation to the violations declared and for satisfaction of the next of kin. The state also had to conduct a public ceremony covered by the media, carry out human rights education and programs for the security sector, as well as create a monument for those who died as a form of reparations.

${ }^{210}$ See Section $4 \mathrm{~B}$ for further discussion. 
The Court could potentially be a vehicle for regional innovation in providing fuller redress to victims. The Court might even require a convicted defendant to participate in local reconciliatory procedures as a means of securing reparations to victims. It is premature to determine how broadly the Court will construe these provisions. But, this would be an improvement on the 'imagined victims' of international justice advocates. These 'imagined victims' always demand retributive justice, when in reality, victims have diverse desires for redress, which also emphasize reparative and restorative justice. ${ }^{211}$ Restorative justice approaches may be especially important for the crime of trafficking in hazardous waste, given the dire consequences that toxic dumping has on public health and the environment. ${ }^{212}$ The detrimental impact of trafficking in hazardous waste for individuals and communities, may mean that imprisonment of traffickers or other retributive measures have less import in achieving justice as conceived by the affected community. This is particularly important in some communities within African countries where justice is conceptualized in 'reference to communal restoration, inter-personal forgiveness, and reconciliation, and redistributive, rather than retributive process. ${ }^{213}$ Consequently, the regional prosecution of trafficking in hazardous waste under Malabo may further restorative justice goals. Thus, Art. 28L would assist with furthering the Bamako Convention's objectives of punishment for traffickers of hazardous waste.

\section{Expressive Condemnation}

The prosecution of trafficking in hazardous waste through the Court may also help to further expressive condemnation goals. Some theorists emphasize the expressive value of punishment, ${ }^{214}$ which is required to reverse the false

${ }^{211}$ See Laurel E. Fletcher, 'Refracted Justice: The Imagined Victim and the International Criminal Court', in Christian De Vos, Sara Kendall, Carsten Stahn, (eds.), 'Contested Justice: The Politics and Practice of the International Criminal Court Interventions', (Cambridge:

Cambridge University Press, 2015) pp. 2, 15 (available at www.law.berkeley.edu/php-programs/ faculty/facultyPubsPDF.php?facID=517\&pubID=41.

${ }^{212}$ See Section $2 \mathrm{~A}$ for further discussion.

${ }^{213}$ Sergey Vasiliev, 'Between International Criminal Justice and Injustice: On the Methodology of Legitimacy', draft paper on file with author, p 29.

${ }^{214}$ See, e.g., Emile Durkheim, 'The Division of Labour in Society', (New York: : Simon and Schuster, 1997); David Luban, 'Fairness to Rightness: Jurisdiction, Legality, and the Legitimacy of International Criminal Law', in Samantha Besson \& John Tasioulaseds, 'The Philosophy of International Law' (New York: : Oxford University Press, 2010) pp. 569, 575; Robert D. Sloane, 'The Expressive Capacity of International Punishment: The Limits of the National Law Analogy and the Potential of International Criminal Law' (2007), 43 Stanford Journal of International Law 39, 42-5; Dan M. Kahan, 'What Do Alternative Sanctions Mean?' (1996), 63 University of Chicago Law Review 597. 
message sent by the offender's actions about the value of the victim relative to the criminal. ${ }^{215}$ These theorists view punishment as a form of moral communication used to express condemnation, revalidate a victim's worth, and strengthen social solidarity. Yet, the ability of the Court to further expressive condemnation goals of punishment may be limited for several reasons. First, regional powers may tend to distort or even abuse regional processes ${ }^{216}$ by using the Court to further political aims or protecting allies from the court's reach. In the same way that powerful actors may shield their allies from potential prosecutions at the domestic or international level, the Court may exhibit the same tendencies. For example, the AU has been notoriously silent on human rights violations taking place in Zimbabwe and other countries with influential or revered leaders. ${ }^{217}$ The Court could then be subject to the criticism that it lacks sufficient political independence, which may limit the ability of the Court to be a robust mechanism for expressing condemnation of trafficking in hazardous waste. Yet, because there are multiple regional hegemons on the Continent, this may counteract the ability of one state to exercise undue influence over the regional criminal chamber. Additionally, there is no reason to think of African states as a monolith -regional hegemons may have drastically different views on expressing condemnation on the trafficking of hazardous waste.

The criminalization of trafficking in hazardous waste may assist in rendering international criminal trials more credible in expressing condemnation. International criminal trials generally focus on individual cases, and not the complex relationships that exist between individuals, groups, institutions, and other entities that make massive violations possible. ${ }^{218}$ And in the effort to move away from collectivizing guilt (which may lead to further violence or recriminations) and instead attempt to individualize guilt, trials often tend to absolve other states, corporations, groups, institutions,

${ }^{215}$ See, e.g., Dan M. Kahan, 'The Anatomy of Disgust in Criminal Law' (1998), 96 Michigan Law Review 1621, 1641; R.A. Duff, 'Penal Communications: Recent Work in the Philosophy of Punishment' (1996), 20 Crime and Justice 1, 8; Jean Hampton, 'An Expressive Theory of Retribution', in Wesley Cragg (ed), Retributivism and Its Critics (Berlin: Franz Steiner Verlag, 1992) pp. 1, 32-3.

${ }^{216}$ See Christoph Schreuer, 'Regionalism v. Universalism' (1995), 6 European Journal of International Law, 477.

${ }^{217}$ See generally Laurence Helfer \& Karen J. Alter, 'Legitimacy \& Lawmaking: A Tale of Three International Courts' (2013), 14 Theoretical Inquiry in Law 479, 502.

${ }^{218}$ See M. V.S. Sirleaf, 'Beyond Truth \& Punishment in Transitional Justice’ (2014), 54 Virginia Journal of International Law [hereinafter Sirleaf, Beyond Truth \& Punishment] (internal citations omitted). 
bystanders, and the rest of society of any responsibility as if individuals committed massive violations in a vacuum. ${ }^{219}$ The focus on establishing individual accountability for a small number of crimes may present the opportunity for many criminal participants including corporations 'to rationalize or deny their own responsibility for crimes, ${ }^{220}$ which limits the ability of such trials to express social solidarity and condemnation. The Court's ability to prosecute trafficking in hazardous waste and the provision for corporate criminal liability may advance the already limited ability of such trials to express social solidarity and condemnation, and thereby increase the credibility of such trials, even if minimally. This improvement while not eliminating some of the problematic tendencies of such trials, would be a welcome development. The regional criminal court in Africa could develop a regional jurisprudence ${ }^{221}$ on trafficking in hazardous waste given the prevalence of these issues in Africa, ${ }^{222}$ which may influence other jurisdictions to express condemnation of this crime. In sum, the regional prosecution of trafficking in hazardous waste may further expressive condemnation goals. Accordingly, Art. 28L of the Malabo Protocol would assist with advancing the Bamako Convention's objectives of punishment for traffickers of hazardous waste through expressive condemnation.

\section{Regional Criminalization of Trafficking in Hazardous Waste and Deterrence}

The prosecution of trafficking in hazardous waste through the Court could also help to further deterrence. Utilitarian theories focus on punishment as a means to achieve some desired end, usually the prevention of future crimes. ${ }^{223}$ Deterrence theories of punishment are based on the rationale that potential perpetrators are dissuaded from committing atrocities due to the risk and fear

\footnotetext{
${ }^{219}$ See id.

220 Laurel E. Fletcher \& Harvey M. Weinstein, 'Violence and Social Repair: Rethinking the Contribution of Justice to Reconciliation' (2002), 24 Human Rights Quarterly 573, 601.

${ }^{221}$ For example, the Inter-American Court of Human Rights has developed a rich jurisprudence on the 'right to truth' and forced disappearances due to the prevalence of authoritarian regimes in the region. See the Preamble of the Inter-American Convention on Forced Disappearances of Persons, Inter-American Commission on Human Rights, Belem do Para, 8 June 1994, in force 28 March 1996 available at www.oas.org/en/iachr/mandate/Basics/disappearance.asp

${ }^{222}$ See Section $2 \mathrm{~B}$.

${ }^{223}$ See generally J. Bentham, 'An Introduction to the Principles of Morals and Legislation', (Buffalo: Prometheus Books, 1988); H.L.A. Hart, 'Punishment and Responsibility: Essays in the Philosophy of Law', (Oxford: Oxford University Press, 2008).
} 
of punishment. ${ }^{224}$ Individual or specific deterrence seeks to prevent future crime by setting sentences that are strict enough to ensure that a particular offender will not reoffend. While general deterrence attempts to prevent crime by inducing others who might be tempted to commit crime, to desist out of fear of the penalty.

The ability of the Court to contribute towards deterrence goals may similarly be limited because it is dependent on member states for cooperation. ${ }^{225}$ In order for deterrence theory to work as applied to the crime of trafficking in hazardous waste - the risk of getting caught and being punished cannot be so low as to be discounted. Yet, the regional Court is dependent on state parties to effectively carry out any investigation and prosecution of trafficking in hazardous waste for everything from the identification and location of persons, to the arrest, detention, and transfer of persons to the Court, as well as the freezing and seizure of assets for forfeiture. ${ }^{226}$ The Court may face significant challenges with trying to increase the likelihood of getting caught for trafficking in hazardous waste. As noted above the illegal trafficking in hazardous waste depends on an underground economy, ${ }^{227}$ which may be exceedingly difficult to investigate, and prosecute. The regional criminal court's inability to prosecute the trafficking in hazardous waste effectively could be even more pronounced because many of the individuals or entities sought will likely be located outside of the Continent, and those located within Africa may not be parties to the Malabo regime. The problem of under-detection was illustrated in the toxic waste scandal in Nigeria. It highlights how detection of the crime of trafficking in hazardous waste is likely to prove difficult. As a result, there is a significant risk that hazardous, even radioactive materials, could be transported and left in Africa undetected until residents begin to suffer severe negative health consequences. Moreover, the domestic prosecution of the U.S. 'war on drugs' demonstrates that unless changes are made on the demand side, cracking down on the suppliers will only lead to more individuals and entities stepping in to fill the roles of those imprisoned. Furthermore, at the international level where crimes of mass atrocity are committed more openly, prosecutions have been anything, but swift or certain, and this is with more

${ }^{224}$ See, e.g., Deirdre Golash, 'The Justification of Punishment in the International Context', in Larry May \& Zachary Hoskins (eds.), 'International Criminal Law and Philosophy'

(Cambridge: Cambridge University Press, 2010) pp. 201, 211 (Immi Tallgren, "The Sensibility and Sense of International Criminal Law' (2002), 13 European Journal of International Law 561.

${ }^{225}$ See art. $46 \mathrm{~L}$ of the Malabo Protocol.

${ }^{226}$ See id.

${ }^{227}$ See Section 2 for further discussion. 
states participating in the Rome Statute regime. ${ }^{228}$ Accordingly, it may be worthwhile to consider supplementary monitoring mechanisms that will help ensure that, if proscribed conduct is violated, the Prosecutor for the regional court will come to learn of these violations.

On the other hand, the Court might be able to contribute to deterrence in other ways. For example, the penalties would have to be adequately publicized regionally to further deterrence. The Malabo Protocol provides that "penalties shall be pronounced in public."229 The Court should make every effort to publicize its sanctions not just before the accused or by word of mouth, but in print, online, and on social media. Moreover, the Court may further deterrence due to the severity of its penalties and sentences for trafficking in hazardous waste. It remains to be seen how the Court will determine its sentences or penalties for those found guilty of trafficking in hazardous waste and whether it will have any impact on marginal deterrence. Because the Court has a lot of latitude under the Protocol to impose penalties and sentences (short of the death penalty), ${ }^{230}$ significant penalties and sentences should be imposed in order to further the goals of specific and general deterrence.

Additionally, some commentators have found that deterrence due to the fear of trials may be more influential for higher-level perpetrators, while deterrence due to the fear of penalties might be more impactful for lowerlevel perpetrators. ${ }^{23^{1}}$ It is not evident whether the unlikely, but more severe punishment of imprisonment or the more likely, but less severe sanction of a fine will deter would-be traffickers in hazardous waste. The Malabo Protocol gives the Court the flexibility of taking individual circumstances into account when imposing sentences or penalties. ${ }^{232}$ This adaptability will be incredibly important for dealing with hazardous waste brokers, as the penalties or sentences imposed on these intermediaries may need to differ from those imposed on those lower or higher-up the 'food-chain.' Unlike retributive justice, deterrence theory does not require the punishment of all equally culpable individuals. Accordingly, the Court's inability to prosecute political

${ }_{228}$ There are 123 countries that are State parties to the Rome Statute; African States form the biggest regional block, with thirty-four state parties. See International Criminal Court, The

State Parties to the Rome Statute www.icccpi.int/en_menus/asp/states\%2oparties/Pages/the\% 2ostates\% 2oparties\% zoto\% zothe\%2orome\% zostatute.aspx (last checked on Oct. 24, 2017).

${ }_{229}$ See art. $43 \mathrm{~A}(3)$ of the Malabo Protocol.

${ }^{230}$ See arts. $43 \mathrm{~A}(1)$ and (2) of the Malabo Protocol.

${ }^{231}$ See Miriam Aukerman, 'Extraordinary Evil, Ordinary Crime: A Framework for Understanding Transitional Justice' (2002), 15 Harvard Human Rights Journal 39, 70.

${ }^{232}$ See art. $43 \mathrm{~A}(4)$ Malabo Protocol. 
leaders that are alleged to have engaged in trafficking of hazardous waste due to the immunity provision, is not fatal from a deterrence perspective. This is because, if exemplary punishments adequately deter future crime that is sufficient. As such, the selective prosecution of 'intermediaries' or lowerlevel perpetrators may suffice to further general deterrence goals. The regional Court could focus its prosecutions on private local companies, individuals, lower-level government officials, as well as waste brokers. This prosecution strategy may be useful because it will be difficult for the Court to obtain jurisdiction over higher-level perpetrators, or individuals and entities outside the Continent. Yet, as the Court grows and begins to increase its credibility, prosecutions of those higher up the food chain could be done more fruitfully.

The Court may also further deterrence because this theory of punishment depends on the perpetrator being a 'rational actor'. The individual(s) contemplating engaging in trafficking must be deterrable and trafficking in hazardous waste is a crime that requires careful planning as opposed to being a crime of hate or passion. Consequently, deterrence theory is expected to work as applied to trafficking in hazardous waste because actors engaging in it are more likely to do a cost-benefit analysis. Indeed, the combination of cheap land and labour for landfill operations, concomitant with looser regulations and enforcement mechanisms in developing countries, means that exporting hazardous waste is a cost-effective option for producers in the Global North, and offers short-term benefits to importers in the Global South. ${ }^{23}$ The Malabo Protocol seeks to disrupt this calculus from the reported $\$ 2.50$ per ton to dump hazardous waste in Africa as opposed to $\$ 250$ per ton in Europe. ${ }^{2} 34$

In addition, actors may not engage in toxic dumping for extra-legal reasons. For example, lower-level perpetrators might simply believe that trafficking in hazardous waste is wrong, or higher-level perpetrators may be more concerned about political isolation regionally or internationally for engaging in trafficking in hazardous waste. For these individuals, the Court's intervention would be expected to have no impact on deterrence. Yet, the net result of these extralegal deterrents would be to reduce the amount of trafficking in hazardous waste. Even if it does so minimally, the Court will further deterrence goals by raising the cost of trafficking in hazardous waste in Africa - by increasing the regulation and prosecution of this crime, or at least increasing the stigma associated with the crime. In sum, Article $28 \mathrm{~L}$ of the Malabo Protocol will

\footnotetext{
233 See Pratt ‘Decreasing Dirty Dumping?’ p. 154.

${ }^{234}$ UNEP Report.
} 
assist with fulfilling the Bamako Convention's requirement that criminal penalties 'be sufficiently high to both punish and deter' trafficking in hazardous waste. ${ }^{235}$

\section{CONCLUSION}

Given the analysis above, there are many reasons to be cautiously optimistic about Article 28L's criminalization of trafficking in hazardous waste and the provision of a regional forum for investigation and prosecution for this crime and others under the Malabo Protocol. While it is unlikely that the regional criminalization of trafficking in hazardous waste will contribute to retribution, there are many theories of punishment that support the Protocol's innovation in this area, including restorative justice, expressive condemnation, and deterrence. It is also important to bear in mind that the proposed Court would be one tool amongst many for combating the trafficking in hazardous waste. While by no means perfect, the Malabo Protocol presents another option for African states whose domestic judiciaries and related institutions may not be able to prosecute trafficking in hazardous waste at all. Additionally, Article $28 \mathrm{~L}$ of the Protocol certainly helps to fulfil many criminal justice goals of the Bamako Convention when compared to the international system, which has failed to prosecute trafficking in hazardous waste or corporations involved in dirty dumping.

235 Art. 9(2) of the Bamako Convention. 